\title{
The Manx shearwater (Puffinus puffinus) as a candidate sentinel of Atlantic Ocean health
}

\author{
Maíra Duarte Cardoso ${ }^{1 *}$, Jailson Fulgencio de Moura², Davi C Tavares ${ }^{3}$, Rodrigo A Gonçalves ${ }^{4}$, \\ Fernanda I Colabuono ${ }^{5}$, Emily M Roges ${ }^{6}$, Roberta Laine de Souza ${ }^{6}$, Dalia Dos Prazeres Rodrigues ${ }^{6}$, \\ Rosalinda C Montone ${ }^{5}$ and Salvatore Siciliano ${ }^{3}$
}

\begin{abstract}
Introduction: Seabirds have been historically used to monitor environmental contamination. The aim of the present study was to test the suitability of a species belonging to the Procellariiformes group, the Manx shearwater, Puffinus puffinus, as a sentinel of environmental health, by determining contaminant levels (trace metals and organochlorine compounds) from carcass tissues and by isolating Vibrio spp. and Aeromonas spp. from live specimens. To this end, 35 Puffinus puffinus carcasses wrecked on the north-central coast of the state of Rio de Janeiro, Brazil, and two carcasses recovered in Aracruz, on the coast of the state of Espírito Santo, Brazil, were sampled, and fragments of muscle and hepatic tissues were collected for contaminant analyses. Swabs from eleven birds found alive at the north-central coast of Rio de Janeiro were collected for isolation of the aforementioned bacteria.

Results: The average concentration in dry weight ( $\mathrm{dw}$ ) of the trace metals were: mercury $7.19 \mathrm{mg} \mathrm{kg}^{-1}$ (liver) and $1.23 \mathrm{mg} \mathrm{kg}^{-1}$ (muscle); selenium $34.66 \mathrm{mg} \mathrm{kg}^{-1}$ (liver) and $7.98 \mathrm{mg} \mathrm{kg}^{-1}$ (muscle); cadmium $22.33 \mathrm{mg} \mathrm{kg}^{-1}$ (liver) and $1.11 \mathrm{mg} \mathrm{kg}^{-1}$ (muscle); and lead, $0.1 \mathrm{mg} \mathrm{kg}^{-1}$ (liver) and $0.16 \mathrm{mg} \mathrm{kg}^{-1}$ (muscle). Organochlorine compounds were detected in all specimens, and hexachlorbiphenyls, heptachlorbiphenyls and DDTs presented the highest levels. Regarding microbiological contamination, bacteria from the Vibrio genus were isolated from $91 \%$ of the analyzed specimens. Vibrio harveyi was the predominant species. Bacteria from the Aeromonas genus were isolated from $18 \%$ of the specimens. Aeromonas sobria was the only identified species.
\end{abstract}

Conclusions: The results indicate that Puffinus puffinus seems to be a competent ocean health sentinel. Therefore, the monitoring of contaminant levels and the isolation of public health interest bacteria should proceed in order to consolidate this species importance as a sentinel.

Keywords: Puffinus puffinus, Brazil, Sentinel, Metal, Organochlorines, Vibrio, Aeromonas

\section{Introduction}

Oceans cover approximately $70 \%$ of the earth surface [1] and about $60 \%$ of the human population lives in coastal areas. Many of these populations depend on the ocean for their subsistence [2].

As environmental degradation accelerates, science has increasingly focused on the influence of the environment on human health. Environmental degradation has direct impacts on life quality and health conditions of the human

\footnotetext{
*Correspondence: mairadc@gmail.com

'Programa de Pós-Graduação em Saúde Pública e Meio Ambiente, ENSP/ Fiocruz, Rua Leopoldo Bulhões, 1480, Manguinhos, Rio de Janeiro 21041-210, RJ, Brasil

Full list of author information is available at the end of the article
}

population [3]. Consequently, ocean processes, which are influenced by human activity, have important public health implications $[4,5]$.

Some substances, such as persistent organic pollutants (POPs), polycyclic aromatic hydrocarbon (PAHs) and toxic metals show negative impacts on the health of humans and other animals and also on the oceans themselves [5-8]. The same is true with regard to pathogenic microorganisms, especially those autochthonous of marine environments, like bacteria from the Vibrio and Aeromonas genera [5,7].

As these substances reach the marine environment, they impact the biota in a negative manner [9]. Metals are naturally present in marine environments, and they only 
become toxic when their concentration levels are increased beyond a certain point [10]. Many organochlorine compounds are synthetic and reach the environment mainly by anthropic action [9]. These two classes of pollutants are persistent in the marine environment and are capable of bioaccumulation and biomagnification in the marine food web [10].

There is a need for coastal countries to develop ocean monitoring strategies [11] and one way of doing this is through the use of sentinel species [12]. These species are capable of accumulating pollutants in their organisms without significant adverse effects and are used to measure the amount of bioavailable pollutants [13]. Seabirds have been historically used as sentinels because they are well-known, conspicuous, ubiquitous, abundant, large, long-living, well-liked by people, and, most importantly, they are top predators in the food chain. This is important, since the determination of pollutants that are capable of bioaccumulation and biomagnification is most adequate in higher level organisms [14-16].

In this context, the present study suggests the use of the Manx shearwater (Puffinus puffinus) as a sentinel of Atlantic Ocean health, as this species fulfills the requisites of a good sentinel species [17]. The oldest specimen ever recorded was over fifty years old [18] and a 31year-old specimen was recovered from the Brazilian coast in 2009 (GEMM-Lagos, unpublished data). Manx shearwater colonies are located in the North Atlantic Ocean, mostly in the United Kingdom [17]. During the northern winter, the Manx shearwater migrates to the South Atlantic Ocean, with the Brazilian coast as its main destination $[17,19]$. The objection that a migratory species should not be used for this purpose, as they are not specific to that particular environment, does not stand when the goal is to gather data at a large scale [14].

Thus, the aim of the present study was to test the usefulness of $P$. puffinus as a sentinel of environmental health, by determining contaminant levels (trace metals and organochlorine compounds) from carcass tissues and by isolating Vibrio spp. and Aeromonas spp. from live specimens.

\section{Results and discussion Biometric data}

The length of the carcasses collected in this study was of $32.88 \pm 0.49$ (mean \pm standard deviation), ranging from
30 to $36 \mathrm{~cm}$. The wingspan was of $72.24 \pm 0.52$ (mean \pm standard deviation), ranging from 69 to $76 \mathrm{~cm}$.

\section{Metal analyses}

Element concentrations are presented in Table 1, as mean \pm standard deviation (SD) and range (min-max) on a dry weight basis. Tables 2 and 3 show the values obtained and the recovery levels of the certified reference material analyses. The method limits of quantification for muscle tissue were $0.02 \mathrm{mg} . \mathrm{kg}^{-1}$ for $\mathrm{Hg}$; $0.072 \mathrm{mg} . \mathrm{kg}^{-1}$ for Se; $0.071 \mathrm{mg}$. $\mathrm{kg}^{-1}$ for $\mathrm{Cd}$; and $0.097 \mathrm{mg} . \mathrm{kg}^{-1}$ for $\mathrm{Pb}$. The limits for hepatic tissue were $0.02 \mathrm{mg} \cdot \mathrm{kg}^{-1}$ for $\mathrm{Hg}$; $0.59 \mathrm{mg} \cdot \mathrm{kg}^{-1}$ for Se; $0.28 \mathrm{mg} \cdot \mathrm{kg}^{-1}$ for $\mathrm{Cd}$; and $0.009 \mathrm{mg} \cdot \mathrm{kg}^{-1}$ for $\mathrm{Pb}$.

The results of this study are in accordance with worldwide literature. Mean $\mathrm{Hg}$ concentrations in P. puffinus hepatic tissue were slightly higher than those reported by Dale et al. [20] but somewhat lower than those reported by Osborn et al. [21]. The means in muscle tissue were somewhat higher than the results by Osborn et al. [21]. These comparisons suggest that mercury concentrations in this species have not varied much from the 1970s to the present day.

Mean hepatic $\mathrm{Cd}$ concentrations in this study are higher than those described by Osborn et al. [21] and Garcia [22], but this is mainly due to outliers. If the median (16.25 mg. $\mathrm{kg}^{-1}$ ) had been used instead of the means, the results would have been very close to those reported by the aforementioned studies. In muscle tissue, Cd concentrations were lower than those described by Osborn et al. [21] and Garcia [22].

Comparing the results of this study with others involving different Puffinus genus species with similar habits, lower metal concentrations are usually reported in species that breed in the southern hemisphere ( $P$. gravis, $P$. assimilis and P. griseus) [23-26]. It is possible that the North Atlantic Ocean, where P. puffinus colonies are located, shows higher metal contamination rates, due to earlier and more intense industrialization, but the differences observed could also be due to different diets within the species [23].

On the other hand, $\mathrm{Cd}$ concentrations reported by Muirhead \& Furness [23] in P. gravis and P. assimilis are almost twice those observed in the present study. Garcia [22] also reported higher concentrations in P. gravis tissues. The concentration of this metal tends to be higher in species whose diet consists of a high amount of cephalopods [23], since these animals are important transfer

Table 1 Metal concentrations tissues of in Puffinus puffinus wrecked at study area

\begin{tabular}{|c|c|c|c|c|}
\hline Tissue & {$[\mathrm{Hg}](\mathrm{dw})\left(\mathrm{mg} \cdot \mathrm{kg}^{-1}\right)$} & {$[\mathrm{Se}](\mathrm{dw})\left(\mathrm{mg} \cdot \mathrm{kg}^{-1}\right)$} & {$[\mathrm{Cd}](\mathrm{dw})\left(\mathrm{mg} \cdot \mathrm{kg}^{-1}\right)$} & {$[\mathrm{Pb}](\mathrm{dw})\left(\mathrm{mg} \cdot \mathrm{kg}^{-1}\right)$} \\
\hline Hepatic $(n=20)$ & $7.19 \pm 3.37(1.16-14.22)$ & $34.66 \pm 20.14(10.56-75.20)$ & $22.33 \pm 25.46(2.31-113.01)$ & $0.1 \pm 0.06(0.036-0.28)$ \\
\hline Muscle $(n=37)$ & $1.23 \pm 0.53(0.47-2.31)$ & $7.98 \pm 3.68(3.17-19.01)$ & $1.11 \pm 1.72\left(<\mathrm{LQ}^{*}-8.94\right)$ & $0.16 \pm 0.09\left(<\mathrm{LQ}^{*}-0.43\right)$ \\
\hline
\end{tabular}

* $<\mathrm{LQ}=$ below the limits of quantification.

Detailed legend: Metal concentrations tissues of in Puffinus puffinus wrecked at study area, from 2005 to 2011. 
Table 2 Analyses and recovery of the certified reference materials (DORM-2)

\begin{tabular}{|c|c|c|c|c|}
\hline Metal & Reference value DORM-2 (mg.kg $\left.{ }^{-1}\right)$ & Mean of obtained values $\left(\mathrm{mg} \cdot \mathrm{kg}^{-1}\right)$ & Recovery (\%) & $\mathbf{n}$ \\
\hline $\mathrm{Cd}$ & $0.043 \pm 0.008$ & 0.04 & $97 \%$ & 3 \\
\hline $\mathrm{Hg}$ & $4.64 \pm 0.26$ & 4.83 & $104 \%$ & 3 \\
\hline $\mathrm{Pb}$ & $0.065 \pm 0.007$ & 0.07 & $104 \%$ & 3 \\
\hline $\mathrm{Se}$ & $1.4 \pm 0.09$ & 1.39 & $99 \%$ & 3 \\
\hline
\end{tabular}

vectors of cadmium in the food chain [27,28]. Cephalopods are important prey in $P$. assimilis, $P$. gravis and $P$. puffinus diets $[17,23,29]$, so it is possible that the species studied by Muirhead \& Furness [23] and Garcia [22] fed on cephalopods that accumulate higher cadmium concentrations, or simply fed on a higher amount of cephalopods, as compared to the P. puffinus specimens analyzed in this study. Differences in the diet of this species can be seen in the study by Petry et al. [29]. Another hypothesis is that the specimens of the previously cited studies were older than those used in the present study, since cadmium tends to accumulate over the years [30].

$\mathrm{Pb}$ concentrations reported in studies involving $P$. gravis and $P$. griseus were very low, in accordance to the present study $[25,26]$. This is due to the biodilution that the element seems to undergo in the marine food chain $[31,32]$.

It is important to highlight that most cephalopod species and all the fish species cited as Manx shearwater food sources in several studies, such as Ammodytes tobianus, Mallotus villosus, Paralonchurus brasiliensis, Clupea genus juveniles and juvenile squid from the Ommastrephidae family $[17,29,33]$, are also consumed by humans, indicating that humans can be exposed to these contaminants through their diet.

\section{Concentrations of the same metal in hepatic and muscle tissues}

Spearman's rank correlation coefficient was used in order to verify the strength of the association between the concentration of an element in the liver and the concentration of the same element in the muscle. The classification of the strength of the association followed the scale described by Bryman \& Cramer [34].

Moderate positive correlations were found between hepatic and muscle $\mathrm{Hg}(\rho=0.50)$ and between hepatic and muscle Se $(\rho=0.48)$. A strong positive correlation was found between hepatic and muscle $\mathrm{Cd}(\rho=0.81)$, and a weak positive correlation, with no statistical significance, was found between hepatic and muscle $\mathrm{Pb}(\rho=0.29)$.

The differences in element concentrations in both tissues can be seen in Figure 1, where all elements, except for $\mathrm{Pb}$, show the same pattern, with higher concentrations in hepatic tissue when compared to muscle.

In birds, $90 \%$ of the existing cadmium is accumulated in the liver and kidneys, the latter being the main site of cadmium toxicity, since kidneys do not resist the toxic effects of cadmium as well as the liver. For this reason, hepatic tissue is considered the best locus to monitor cadmium exposition. It is also the best choice for monitoring mercury and selenium exposure [35]. This is possibly the reason why, in the present study, Cd levels in the liver were always higher than in muscle.

In this study, $\mathrm{Pb}$ behaved differently from the other analyzed metals, but it is important to note that $\mathrm{Pb}$ levels were very low and the differences between muscle and liver concentrations were very small. In birds, this element accumulates primarily in the bones and among the soft tissues, with the primary accumulation site being the kidneys $[35,36]$. It is known that lead can occupy the binding sites of calcium [37], so this is possibly the reason why, in the present study, the element was found at its highest concentration in muscle tissues.

\section{Interelemental relationships}

The correlations between the elements were tested by the Spearman's rank correlation coefficient. Very weak positive correlations, with no statistical significance, were found between $\mathrm{Hg}$ and $\mathrm{Se}(\rho=0.05)$ and $\mathrm{Se}$ and $\mathrm{Cd}$ $(\rho=0.04)$, both in muscle tissue; and also between $\mathrm{Cd}$ and $\mathrm{Pb}(\rho=0.16)$ and $\mathrm{Hg}$ and $\mathrm{Pb}(\rho=0.10)$, both in hepatic tissue. Very weak negative correlations, with no statistical significance, were found between $\mathrm{Hg}$ and $\mathrm{Cd}(\rho=-0.04)$ and $\mathrm{Hg}$ and $\mathrm{Pb}(\rho=-0.06)$, both in muscle tissue. Weak positive correlations, with no statistical significance, were

Table 3 Analyses and recovery of the certified reference materials (DOLT-3)

\begin{tabular}{cccc}
\hline Metal & Reference value DORM-2 (mg.kg-1) & Mean of obtained values (mg.kg-1) & Recovery (\%) \\
\hline Cd & $19.4 \pm 0.6$ & 17.45 & $\mathbf{n}$ \\
$\mathbf{H g}$ & $3.37 \pm 0.14$ & 3.17 & 3 \\
$\mathrm{~Pb}$ & $0.319 \pm 0.045$ & 0.29 & $94 \%$ \\
$\mathrm{Se}$ & $7.06 \pm 0.48$ & 6.98 & $92 \%$ \\
\hline
\end{tabular}



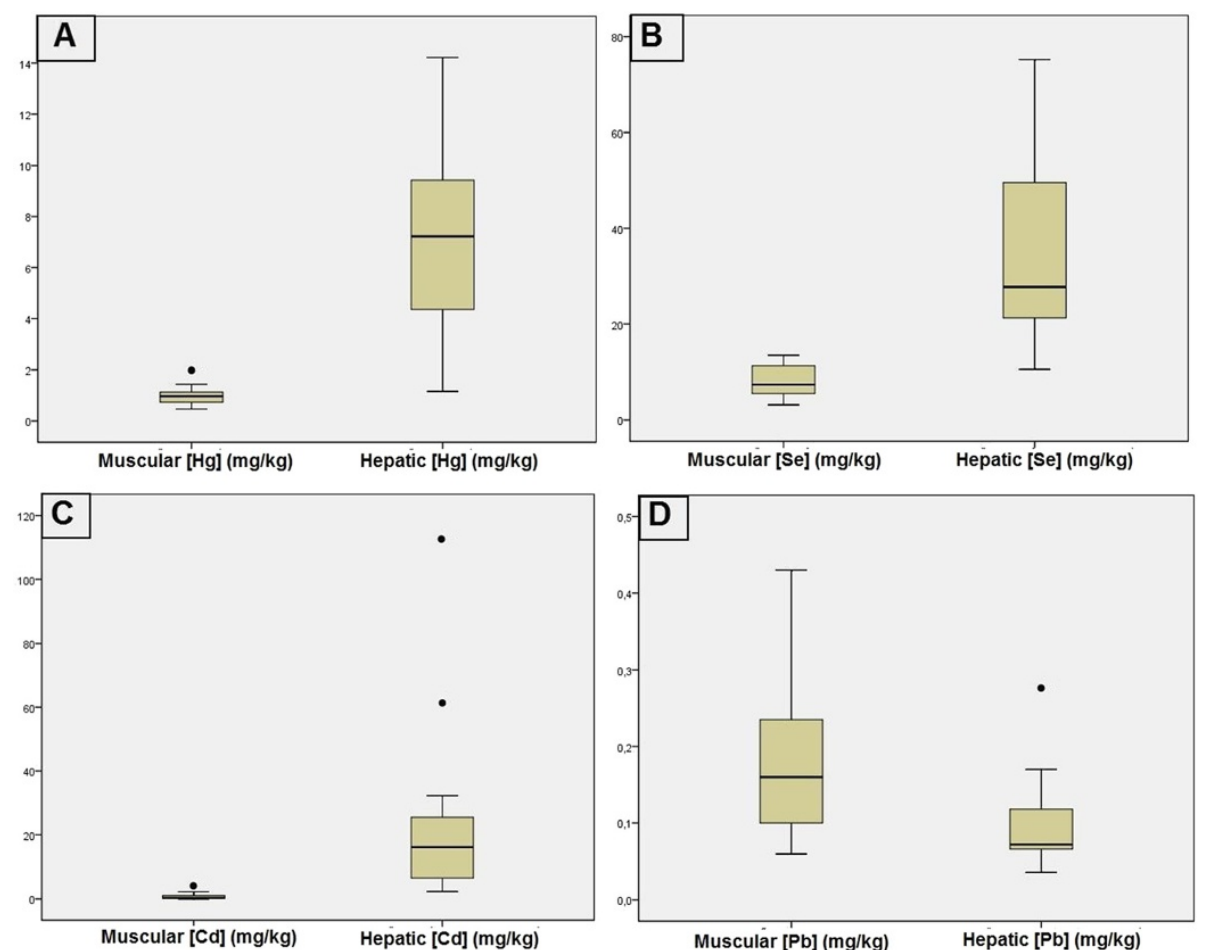

Figure 1 Differences between muscle and hepatic metal concentrations in Puffinus puffinus tissues. Detailed legend: Differences between muscle $(n=37)$ and hepatic $(n=20)$ metal concentrations in Puffinus puffinus wrecked at the study area, from 2005 to $2011 . \mathbf{A}=[\mathrm{Hg}] ; \mathbf{B}=[\mathrm{Se}]$; $\mathbf{C}=[\mathrm{Cd}] ; \mathbf{D}=[\mathrm{Pb}]$.

found between $\mathrm{Se}$ and $\mathrm{Pb}(\rho=0.20)$ and $\mathrm{Cd}$ and $\mathrm{Pb}$ $(\rho=0.20)$, both in muscle tissue; and the same was observed between $\mathrm{Se}$ and $\mathrm{Pb}$ in hepatic tissue $(\rho=0.20)$.

However, some statistically significant correlations were found, such as the moderate positive correlations found between $\mathrm{Hg}$ and $\mathrm{Se}(\rho=0.46), \mathrm{Hg}$ and $\mathrm{Cd}$ ( $\rho=0.52)$ and Se and $C d(\rho=0.50)$, all in hepatic tissue.

Selenium and mercury tend to co-accumulate in bird livers, where selenium acts in reducing mercury toxicity [38-40], although this detoxifying process is not well elucidated. Some possible mechanisms involved in this are the redistribution of mercury throughout the organism in the presence of selenium; competition between the two elements for binding sites; formation of complexes between these elements; conversion of toxic forms of mercury into less toxic forms, such as the demethylation of methyl mercury by selenium; and prevention of oxidative stress caused by mercury $[38,41,42]$.

In marine mammals, a molar ratio of $1: 1$ between $\mathrm{Hg}$ and $\mathrm{Se}$ is found when Se is being used to detoxify $\mathrm{Hg}$ and vice-versa [43]. In birds, this ratio is almost never found $[38,43,44]$, as in the present study, where a $1: 5$ ratio was found. This is possibly the reason why the correlation between $\mathrm{Hg}$ and Se found here is moderate, and not strong or very strong, as has been reported in several studies involving marine mammals [45-47], since this protection mechanism seems to be inherent to marine mammals [43]. Other studies involving aquatic birds have found a larger quantity of selenium relative to mercury, precluding the 1:1 molar ratio, as in the present study $[42,44,48]$.

Current literature has also suggested a correlation between $\mathrm{Se}$ and $\mathrm{Cd}$ in marine birds [30]. Besides detoxifying mercury, selenium can also detoxify cadmium in these organisms, probably by altering the availability of this metal [30].

Selenium seems to be highly effective against damage caused by cadmium and also against methyl mercury and inorganic mercury toxicity, and seems to have very little effect against lead toxicity [41]. This is possibly the reason why, in the present study, $\mathrm{Se}, \mathrm{Cd}$ and $\mathrm{Hg}$ showed correlations, while $\mathrm{Pb}$ did not.

\section{Organochlorine compounds analyses}

Organochlorine compound concentrations are presented in Table 4, as a sum of each group and range (min-max) in ng. $\mathrm{g}^{-1}$, on a dry weight basis.

In this study, organochlorines were found in all specimens. Among the OCPs, the DDT group predominated, especially pp' DDE. Among the PCBs, there was a predominance of hexachlorbiphenyls and heptachlorbiphenyls.

The standard deviation for each compound was extremely high, which indicates great individual variation 
Table 4 Concentrations of organochlorine compounds in tissues of Puffinus puffinus wrecked at study area

\begin{tabular}{|c|c|}
\hline Compounds & Results $(d w)\left(n g \cdot g^{-1}\right)(n=13)$ \\
\hline$\Sigma \mathrm{HCHs}^{(\mathrm{a})}$ & $<\mathrm{LQ}^{*}$ \\
\hline HCB & $16.7(5.97-34.3)$ \\
\hline$\Sigma$ Chlordanes $^{(\mathbf{b})}$ & $9.59\left(<L Q^{*}-20.8\right)$ \\
\hline ¿Drins $^{(\mathrm{c})}$ & $31.39\left(<L Q^{*}-65.2\right)$ \\
\hline$\sum D D T s^{(d)}$ & $193.42\left(<L^{*}-626.0\right)$ \\
\hline Endosulfan II & $<\mathrm{LQ}^{*}$ \\
\hline Metoxychlor & $<\mathrm{LQ}^{*}$ \\
\hline Mirex & $8.94\left(<L Q^{*}-36.9\right)$ \\
\hline$\Sigma \mathrm{PCBs}^{(\mathrm{e})}$ & $729.16\left(<L Q^{*}-632.0\right)$ \\
\hline
\end{tabular}

${ }^{(a)}=$ sum of means of $a-, \beta-, \gamma^{-}$and $\delta$-isomer; ${ }^{(b)}=$ sum of means of $\gamma^{-}$,

a -chlordane, oxychlordane, heptachlor and heptachlor epoxide A and B;

${ }^{(c)}=$ sum of means of aldrin, endrin, isodrin and dieldrin; ${ }^{(d)}=$ sum of means of $\mathrm{pp}^{\prime} \mathrm{DDT}$, op' DDT, pp' DDE, op' DDE, $\mathrm{pp}^{\prime} \mathrm{DDD}$ and $\mathrm{op}^{\prime} \mathrm{DDD}{ }^{(\mathrm{e})}=$ sum of means of 51 congeners; ${ }^{*}<\mathrm{LQ}=$ below limits of quantification.

Detailed legend: Concentrations of organochlorine compounds in tissues of Puffinus puffinus wrecked at study area, from 2005 to 2011.

in the contaminant burden. This variation is expected in long-living birds with delayed sexual maturity, even among specimens at the same maturity stage. This can be related to distribution, migration, diet or age of the individuals [49]. The fact that $P$. puffinus is a migratory species must also be taken into account, which makes it likely that different individuals have different diets depending on the places visited throughout the migration period, reflecting the contamination of breeding and migration sites [50].

In the DDT group, pp' DDE was predominant and found in greater quantities among all the OCPs, in accordance with other studies $[49,51]$. This compound is usually found in the tissues of top predators due to its stability, bioconcentration and bioaccumulation [52]. In birds, DDT is metabolized to DDD and DDE, and DDD to DDE and DDMU, therefore it is normal that DDT and DDD concentrations decrease while DDE increases [53].

$\mathrm{HCHs}$ were not detected in any sample, probably due to the rapid metabolization and elimination that these compounds undergo in birds [54].

Oxychlordane is a metabolite belonging to the chlordanes group. It is persistent and presents difficult biotransformation in seabirds. It is therefore accumulated in greater amount in these organisms than other compounds of the group $[49,55]$. However, in the present study, this compound was only detected in five specimens and in very low concentrations.

From the drins group, only dieldrin was detected. This can be due to the rapid metabolization of aldrin into dieldrin and to the storage of this form in animals [56]. Isodrin is an aldrin isomer and endrin may not have been detected due to its rapid metabolization and excretion [57].
Endosulfan and methoxychlor are also metabolized and excreted fairly quickly [58,59], which may explain their absence in the analyzed tissues. In contrast, $\mathrm{HCB}$ and mirex, compounds of great persistance in the environment and biota $[60,61]$, were present in the specimens analyzed in this study.

With regard to PCBs, there was a predominance of hexachlorbiphenyls and heptachlorbiphenyls (Figure 2). This is due to the fact that birds tend to metabolize and excrete low molecular weight PCBs congeners and accumulate high weight congeners that present a higher degree of halogenation [62].

In another study involving P. puffinus, in addition to other Procellariiformes, conducted at Rio Grande do Sul, Brazil, by Colabuono et al. [49], a similar pattern of contamination was found in tissues: a predominance of pentachlorobiphenyls, hexachlorobiphenyls and heptachlorobiphenyls among PCBs and a predominance of DDTs, especially DDE, among the OCPs. A predominance of DDE has also been reported by Bourne \& Bogan [51], in a study involving seabirds from the North Atlantic, including the Manx shearwater. However, in contrast to the present study and to Colabuono et al. [49], uniformity in organochlorine levels was detected in the analyzed bird tissues.

In another study involving this species, higher levels of pp' DDE and lower levels of PCBs were reported in tissues of specimens from the Mediterranean and from the Black Sea [63]. Another study conducted in Brazil detected all of the analyzed PCBs congeners and, in contrast to the present study, pentachlorobiphenyls were predominant and levels of hexa- and heptacholobiphenyls were low [64].

\section{Microbiological analyses}

Bacteria from the Vibrio genus were detected in $90 \%$ of the analyzed specimens $(\mathrm{n}=11)$, with $V$. harveyi being the most frequent species, followed by Vibrio mediterranei

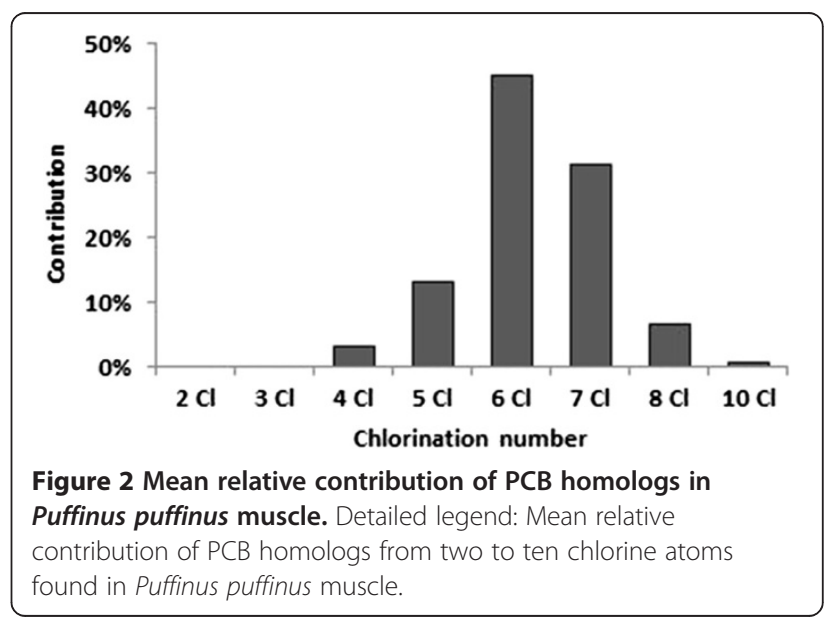


and $V$. parahaemolyticus, each one present in $19 \%$ of the cases. Other species were also isolated: V. fluvialis (7\%), $V$. fisheri (7\%), V. cincinnatiensis (7\%), V. orientalis (4\%), $V$. cholerae non-01/non-0139 (4\%), V. gazogenes (4\%) and $V$. alginolyticus (4\%). In $3 \%$ of the cases, classification by species was not possible.

Bacteria from the Aeromonas genus were isolated in only $18 \%$ of the specimens $(n=11)$ and in most cases $(67 \%)$, classification by species was not possible. In the remaining cases (33\%), only one species was isolated: Aeromonas sobria.

Vibrio anguillarum and $V$. tapetis are the bacteria most frequently related to diseases in aquatic animals [65]. None of these was isolated in the present study. Some species are known to cause diseases in both animals and humans, being potential zoonoses agents, such as $V$. alginolyticus, $V$. harveyi, $V$. cholerae, $V$. fluvialis, $V$. furnissii, V. mimicus, $V$. metschnikovii, V. parahaemolyticus and $V$. vulnificus [65]. Attention should be paid to the fact that five of these species were isolated in the present study, considering that an important infection route for animals and humans is through contaminated seafood [66,67].

Some coincident species were isolated in studies involving aquatic birds in the USA [68,69], Brazil [70], Japan [66] and England [71].

Migratory birds, such as the Manx shearwater, are important dispersers of micro-organisms. Additionally, when migrating, these birds tend to meet at certain locations, which facilitates interindividual and interspecies transmission, even more so since migration stress contributes in decreasing resistance to infection [72]. An important pathogen that can be carried by migratory seabirds is Vibrio cholerae [67,72], which can allow for cholera outbreaks in regions distant from endemic areas [72]. In this study, as in the study of Lee et al. [71], and as was the case of most birds studied by Ogg et al. [68], the Vibrio cholerae isolated was not from the $\mathrm{O} 1$ or O139 serogroups, which are responsible for cholera disease [73].

In some Vibrio species, such as $V$. vulnificus, $V$. parahaemolyticus and $V$. cholera, survival is related to water temperature, with most infections taking place during summer, through the consumption of contaminated seafood or through contact of contaminated water with wounds [65,66,71]. With this in mind, some studies $[66,71]$ were able to isolate these species in aquatic birds even during winter, when the frequency of isolation in water was low, which demonstrates that these bacteria can multiply in birds even when environmental conditions are not favorable and that the survival of this species in the gastrointestinal tract by just a few days is already sufficient to disperse those microorganisms throughout large distances [71].
The study area (north-central coast of Rio de Janeiro) is under influence of the Cabo Frio upwelling, which causes a decrease in water temperatures during spring and summer, due to an outcropping of cold, deep and nutrient-rich waters (South Atlantic Central Water, SACW) [74]. From September to April, the surface water temperature rarely exceeds $18^{\circ} \mathrm{C}$, and in deeper waters, it is often below $15^{\circ} \mathrm{C}[74,75]$. Coincidentally, this is the period when the Manx shearwater is present in the Brazilian coast. Therefore, the species may be an important Vibrio spp. carrier when the water temperature is low.

With regard to Aeromonas spp., some species also depend on warmer waters to survive, as most isolations and cases of gastroenteritis caused by this genus also occur during summer [76-78]. This fact suggests that the hypothesis that waterfowl are sponsors for these microorganisms during periods of unfavorable environmental temperature can also be applied here, and the period of the influence of the upwelling on the study area should be taken into account.

In a study regarding the source of diarrhea infections caused by Aeromonas spp., Moyer [77] reported that some patients may have been contaminated by the ingestion of bivalves and by fishing and swimming in untreated waters. In addition, one of the patients worked at a fish market. These forms of infection indicate the importance of aquatic animals in the transmission of diseases caused by Aeromonas spp., and aquatic birds are among those most related as carrying different species from the genus in their gastrointestinal tract [79].

In two studies conducted in Canada, Lévesque et al. $[80,81]$ isolated high concentrations of Aeromonas spp. from ring-billed gulls feces. These studies emphasize the importance of monitoring these bacteria, as birds can contaminate recreational waters through feces, which may lead to contamination of humans by means of contact between wounds with water or through the ingestion of contaminated seafood [80,81].

\section{Conclusions}

The present study leads to the conclusion that Manx shearwater seems to be an effective sentinel of Atlantic Ocean health, since different types of chemical contaminants could be detected in their tissues and common species of bacteria from aquatic environments could be isolated from swabs collected from this species.

In the present study, metal levels were in accordance with other studies involving this species. The same occurred concerning the pattern of contamination of organochlorine compounds. The results reflect the environmental contamination in breeding sites and throughout the migration route. 
As described, $P$. puffinus feeds on fish species and cephalopods which are also consumed by humans, which highlights the contribution of this study to the public health field. It is worth emphasizing the importance of beach monitoring activities in an effort to prevent contamination.

It is recommended that contaminant levels and the frequency of micro-organisms isolation continue to be monitored in this species and in others, in order to evaluate a possible increase in environmental degradation. It is also important to continue studying the species in order to consolidate the Manx shearwater as a sentinel species.

\section{Methods}

For the purposes of this study, between 2005 and 2011, thirty-five carcasses of wrecked Manx shearwater were collected during beach monitoring at the north-central coast of the state of Rio de Janeiro (from Saquarema south, $22^{\circ} 55^{\prime} 12^{\prime \prime S}$; 42 $30^{\prime} 37^{\prime \prime} \mathrm{W}$ - to São Francisco do Itabapoana - north, $\left.21^{\circ} 18^{\prime} 07^{\prime \prime} S ; 40^{\circ} 57^{\prime} 4^{\prime \prime} \mathrm{W}\right)$ and two carcasses were collected at Aracruz (19 49'13"S; $40^{\circ}$ 16 '24"W), in the state of Espírito Santo, Brazil. The carcasses were measured, necropsied and fragments of hepatic and muscle tissues were collected and stored at $-20^{\circ} \mathrm{C}$ for contaminant analyses. For the metal analyses, 37 muscle samples and 20 liver samples were used. For the organochlorine compounds analyses, 13 muscle samples were used. Most carcasses were found in 2010, a year of severe mortality for this species on the Southeastern coast of Brazil.

Furthermore, from 2009 to 2012, cloaca, oral, ocular and tracheal swabs were collected from eleven specimens found alive on beaches of the north-central coast of Rio de Janeiro (from Saquarema to São Francisco do Itabapoana) for the analysis of bacteria from the Vibrio and Aeromonas genera.

\section{Analytical methods for metal analyses}

The determination of cadmium $(\mathrm{Cd})$, lead $(\mathrm{Pb})$ and selenium (Se) levels was performed by inductively coupled plasma mass spectrometry (ICP-MS). The determination of mercury $(\mathrm{Hg})$ levels was performed by cold vapor atomic absorption spectrometry (CV-AAS).

Samples were defrosted and homogenized with a food microprocessor (HC31 Black \& Decker). For Cd, Pb and Se analyses, approximately $0.5 \mathrm{~g}$ of each muscle sample, in triplicate, and approximately $0.1 \mathrm{~g}$ of each liver sample in duplicate were digested with $5 \mathrm{~mL}$ and $1 \mathrm{~mL}$ of nitric acid $\left(\mathrm{HNO}_{3}\right)$ (Vetec), respectively, in a heating block (Quimis) $\left(80^{\circ} \mathrm{C}\right)$, until total dissolution. Three procedural blanks were prepared with each sample batch in the heating block. Ultra-pure water (obtained from Master All water purificator, Gehaka) was added until a final volume of $50 \mathrm{~mL}$ was reached. Metal concentrations were determined using an ICP-MS 7500 Series (Agilent Technologies).

For the $\mathrm{Hg}$ analyses, approximately $0.5 \mathrm{~g}$ of each muscle sample and approximately $0.1 \mathrm{~g}$ of each liver sample, both in duplicate, were digested with $5 \mathrm{~mL}$ of a sulphuric-nitric acid mixture (HNO3/H2SO4/V2O5) (Vetec) in a heating block $\left(80^{\circ} \mathrm{C}\right)$, until total dissolution. The procedural blanks were performed in the same manner applied to the previous analyses. The samples and the blanks were then cooled and $5 \mathrm{~mL}$ of $\mathrm{KMnO}_{4}$ $5 \%$ (Vetec) were added. The purpose of this process was to ensure that mercury remained in the sample until reading was performed. At this moment, $1 \mathrm{~mL}$ of hydroxylamine (Vetec) was added and then ultra-pure water, until a final volume of $50 \mathrm{~mL}$ was reached. Finally, concentrations were determined using a 3300 spectrometer (Perkin Elmer).

The accuracy of the analytical methods was ensured by the use of Merck certified material $(\mathrm{Hg}, \mathrm{Cd}, \mathrm{Pb}$ and Se Titrisol Standard Solutions) and the quality of the methods used was ensured by the use of National Research Council of Canada certified reference materials (DORM-2 - Dogfish Muscle Certified Reference Material for Trace Metals; and DOLT-3 - Dogfish Liver Certified Reference Material for Trace Metals), analyzed in parallel, in triplicate, with average recovery ranging from $90 \%$ to $104 \%$.

Samples were analyzed as wet weight and, subsequently, aliquots of all samples were weighed and dried in a $315 \mathrm{SE}$ oven (Fanem) until constant weight. This procedure made it possible to obtain humidity factors, which were applied to the results in order to convert them into dry weight.

The limits of quantification (LQ) were provided by equipment software, using the formula: $\mathrm{LQ}=\left[10^{*}\right.$ (SDbr)]/S, where SDbr is the standard deviation from 10 blank readings, and $S$ is the inclination of the calibration curve. This formula provides the instrumental LQ. In order to calculate the final LQ, this formula was multiplied by the dilution factor.

\section{Analytical methods for organochlorine compounds analyses}

The organochlorine pesticides (OCPs) analyzed in this study were: hexachlorocyclohexanes $(\mathrm{HCH})(\alpha-, \beta-, \gamma$ - and $\delta$-isomer), hexachlorobenzene ( $\mathrm{HCB})$, heptachlor, heptachlor epoxide A and B, chlordanes (oxychlordane, $\alpha$ - and $\gamma$ - chlordane), drins (aldrin, isodrin, dieldrin, endrin), dichlorodiphenyltrichloroethane (op' DDT, pp' DDT) and its metabolites, dichlorodiphenyldichloroethylene (op' DDE, pp' DDE) and dichlorodiphenyldichloroethane (op' DDD, pp' DDD), endosulfan II, methoxychlor and mirex. The analyzed polychlorinated biphenyls (PCBs) congeners were the following IUPAC numbers: 8, 28, 31, 33, 44, 49, 52, 56/ 
$60,66,70,74,77,81,87,95,97,99,101,105,110,114,118$, $123,126,128,132,138,141,149,151,153,156,157,158$, $167,169,170,174,177,180,183,187,189,194,195,203$, 206 and 209.

The analytical procedure followed the protocol described by MacLeod et al. (1986) [82], with minor modifications, as described by Colabuono et al. (2012) [49].

At first, 2,2,4,5',6-pentachlorobiphenyl (PCB 103) and 2,2,3,3,4,5,5,6-octachlorobiphenyl (PCB 198) were added to all samples, blanks and reference material as surrogates for OCPs and PCBs. Then, approximately $2.5 \mathrm{~g}$ of each lyophilized muscle sample were extracted in a Soxhlet apparatus for $8 \mathrm{~h}$ using $80 \mathrm{~mL}$ of $\mathrm{n}$-hexane and methylene chloride $(1: 1, \mathrm{v} / \mathrm{v})$. The determination of extractable lipids was made by gravimetric analyses. The extracts were cleaned-up through the use of column chromatography with $8 \mathrm{~g}$ of silica and $16 \mathrm{~g}$ of alumina, both $5 \%$ water deactivated, eluted with $80 \mathrm{~mL}$ of $\mathrm{n}$ hexane and methylene chloride $(1: 1, \mathrm{v} / \mathrm{v})$. The fraction was purified once again, in order to remove lipid excess, now through high-performance liquid chromatography (HPLC), using methylene chloride as eluent with a flow of $5 \mathrm{~mL} \mathrm{~min}^{-1}$. The extract was concentrated to a volume of $0.9 \mathrm{~mL}$ in hexane. The internal standard 2,4,5,6-tetrachlorometaxylene (TCMX) was added before the gas chromatographic analysis was undertaken and a procedural blank was included in the set of samples.

Identification and quantification analyses of the organochlorine pesticides were performed with a $6890 \mathrm{~N}$ gas chromatograph with an electron capture detector (GCECD) (Agilent Technologies), using a $30 \mathrm{~m} \times 0.25 \mathrm{~mm}$ i.d. capillary column coated with $5 \%$ phenyl-substituted dimethylpolysiloxane phase $(0.5 \mu \mathrm{m}$ film thickness $)$. Automatic splitless injections of $2 \mu \mathrm{L}$ were applied and the total purge rate was adjusted to $50 \mathrm{~mL} \mathrm{~min}{ }^{-1}$. The carrier gas used was hydrogen (constant pressure of $40 \mathrm{kPa}$ at $100^{\circ} \mathrm{C}$ ), and the makeup gas was nitrogen, at a rate of $60 \mathrm{~mL}$ min -1 . Injector and detector temperatures were $280^{\circ} \mathrm{C}$ and $320^{\circ} \mathrm{C}$, respectively. Oven temperature was programmed as follows: $70^{\circ} \mathrm{C}$ for $1 \mathrm{~min}$, raised at $40^{\circ} \mathrm{C} \cdot \mathrm{min}^{-1}$ until $170^{\circ} \mathrm{C}$, then raised at $1.5^{\circ} \mathrm{C} \cdot \mathrm{min}^{-1}$ until $230^{\circ} \mathrm{C}$ (held for $1 \mathrm{~min})$, and at $20^{\circ} \mathrm{C} \cdot \mathrm{min}^{-1}$ until $300^{\circ} \mathrm{C}$ with a final hold of $5 \mathrm{~min}$.

The quantitative PCBs analyses were performed by a $5973 \mathrm{~N}$ gas chromatograph coupled to a mass spectrometer (GC-MS) (Agilent Technologies), in a selected ion mode (SIM $70 \mathrm{eV}$ ), using a $30 \mathrm{~m} \times 0.25 \mathrm{~mm}$ i.d. capillary column coated with $5 \%$ phenyl-substituted dimethylpolysiloxane phase $(0.25 \mu \mathrm{m}$ film thickness). Injections were made with $1 \mu \mathrm{L}$ in automatic splitless mode. The carrier gas was helium (constant flow of $1.1 \mathrm{~mL} \mathrm{~min}^{-1}$ ). The interface, source and quadrupole temperatures were $280^{\circ} \mathrm{C}$, $300^{\circ} \mathrm{C}$ and $200^{\circ} \mathrm{C}$, respectively. Oven temperature was programmed as follows: $75^{\circ} \mathrm{C}$ for $3 \mathrm{~min}$, raised at $15^{\circ} \mathrm{C}$. min $^{-1}$ until $150^{\circ} \mathrm{C}$, then raised at $2.0^{\circ} \mathrm{C} \cdot \mathrm{min}^{-1}$, until $260^{\circ} \mathrm{C}$ and at $20^{\circ} \mathrm{C} \cdot \mathrm{min}^{-1}$, until $300^{\circ} \mathrm{C}$ with a final hold of $10 \mathrm{~min}$.

The analytical methodology was validated through the use of a standard reference (SRM 1945 - organics in whale blubber), from the National Institute of Standards and Technology, USA, for quality assurance and quality control. This material was analyzed in parallel, in duplicate, with an average analyte recovery inside the range accepted by the NS\&T [83]. The same occurred in the analyte recovery in spiked blanks and matrices (67$115 \%)$. Analytes in laboratory blanks were subtracted from the samples. Analyte quantification was performed using a nine-level analytical curve following the internal standard procedure. All solvents were residue-analyzed grade from JT Baker. Standard solutions were from AccuStandard. Surrogate recoveries were acceptable and presented mean \pm standard deviation $=97 \pm 7$. Method limits of quantification (LQ) ranged from $1.02 \mathrm{ng} \cdot \mathrm{g}^{-1}$ to $8.5 \mathrm{ng}^{-g^{-1}}$ dry weight $(\mathrm{dw})$.

\section{Analytical methods for microbiological analyses}

Cloacal, oral, ocular and tracheal swabs were carefully collected in order to avoid external contamination and accommodated in Cary-Blair media for transportation.

Samples were enriched with Alkaline Peptone Water (APW) containing $1 \%$ sodium chloride $(\mathrm{NaCl})\left(37^{\circ} \mathrm{C} / 18\right.$ 24 hours). Samples were then streaked onto Thiossulfate Citrate Bile Salts Sucrose Agar (TCBS) and onto Glutamate Starch Phenol Red Agar (GSP) and incubated to $37^{\circ} \mathrm{C}$ over night (model 31483, Thelco). Suspected colonies were transferred to Kligler Iron Agar, Lysine Iron Agar and Nutrient Agar with $1 \% \mathrm{NaCl}$. Posteriorly, biochemical tests were performed in order to identify species from the Vibrionaceae and Aeromonadaceae families, according to Noguerola \& Blanch (2008) [84] and Janda \& Abbott (2010) [85], respectively.

\section{Statistical analyses}

Statistical analyses were performed using the SPSS Statistics 17.0 software (IBM). Results from metal, organochlorine and bacteriological analysis were analyzed separately. Basic descriptive statistics was conducted. Data were tested for normal distribution using the Shapiro-Wilk's test. Since most data were not normally distributed, nonparametric tests were used. Spearman's rank correlation coefficient was used to verify the strength of the association between the concentration of the same metal in hepatic and muscular tissue and to verify the strength of the association in interelement relationship. A p-value of less than 0.05 was used to indicate statistical significance. For bacteriological analyses, the frequencies of isolation of Vibrio spp. and Aeromonas spp. were calculated, as well as the frequency of isolation of each species. 


\section{Competing interests}

The authors declare that they have no competing interests.

\section{Authors' contributions}

MDC conceived of the study, carried out metal and statistical analyses and drafted the manuscript; JFM and DCT collected samples in the field, carried out necropsies and helped in several steps, including metal and statistical analyses and in the drafting of the manuscript; RAG helped in the metal analyses; FIC and RCM carried out the organochlorine compound analyses; EMR, RLS and DPR carried out the microbiological analyses; SS conceived the study, participated in its design and coordination and helped draft the manuscript. All authors read and approved the final manuscript.

\section{Acknowledgements}

To CAPES (Coordination of Improvement of Higher Education Personnel) for the financial support; to Reinaldo Calixto de Campos (in memoriam) for allowing the use of the Laboratory of Atomic Absorption (LAATOM) at PUC-Rio; and to all employees of all the laboratories involved in this work.

\section{Author details}

${ }^{1}$ Programa de Pós-Graduação em Saúde Pública e Meio Ambiente, ENSP/ Fiocruz, Rua Leopoldo Bulhões, 1480, Manguinhos, Rio de Janeiro 21041-210, RJ, Brasil. 'Systems Ecology, Leibniz Center for Tropical Marine Ecology (ZMT), Fahrenheitstrasse 6, 28359 Bremen, Germany. ${ }^{3}$ Departamento de Endemias Samuel Pessoa - DENSP \& Grupo de Estudos de Mamíferos Marinhos da Região dos Lagos - GEMM-Lagos, Escola Nacional de Saúde Pública /FICORUZ, Rua Leopoldo Bulhões, 1.480, $6^{\circ}$ andar, Sala 611, Manguinhos, Rio de Janeiro 21041-210, RJ, Brasil. Departamento de Química, Pontifícia Universidade Católica do Rio de Janeiro, Rua Marquês de São Vicente, 225, Gávea, Rio de Janeiro 22453-900, RJ, Brasil. ${ }^{5}$ Universidade de São Paulo, Instituto Oceanográfico, Praça do Oceanográfico 191, Cidade Universitária, São Paulo 05508-120, SP, Brasil. ' Instituto Oswaldo Cruz/FIOCRUZ, Laboratório de Referência Nacional de Enteroinfecções Bacterianas, Av. Brasil, 4365, Manguinhos, Rio de Janeiro 21040-360, RJ, Brasil.

Received: 24 September 2013 Accepted: 29 August 2014

Published: 1 September 2014

\section{References}

1. Odum EP, Barret GW: Ecologia Regional: Principais Tipos de Ecossistemas e Biomas. In Fundamentos de Ecologia. 5th edition. Edited by Odum EP, Barret GW. São Paulo: Cengage Learning; 2008:412-458.

2. Joint Group of Experts on the Scientific Aspects of Marine Environmental Protection (GESAMP): Protecting the Oceans from Land-Based Activities. New York: 2001.

3. Augusto LGS, Câmara VM, Carneiro FF, Câncio J, Gouveia N: Saúde e Ambiente: uma reflexão da Associação Brasileira de Pós-Graduação em Saúde Coletiva - ABRASCO. Rev Bras Epidemiol 2003, 6(2):87-94.

4. Laws EA, Fleming LE, Stegeman JJ: Centers for Oceans and Human Health: contributions to an emerging discipline. Environl Health 2008, 7:1-5.

5. Kite-Powell HL, Fleming LE, Backer LC, Faustman EM, Hoagland P, Tsuchiya A, Younglove LR, Wilcox BA, Gast RJ: Linking the oceans to public health: current efforts and future directions. Environ Health 2008, 7:1-15.

6. Knap A, Dewailly E, Furgal C, Galvin J, Baden D, Bowen RE, Depledge M, Duguay L, Fleming LE, Ford T, Moser F, Owen R, Suk WA, Unluata U: Indicators of ocean health and human health: developing a research and monitoring framework. Environ Health Perspect 2002, 110(9):839-845.

7. Fleming LE, Broad K, Clement A, Dewailly E, Elmir S, Knap A, Pomponi SA, Smith S, Solo-Gabriele H, Walsh P: Oceans and human health: emerging public health risks in the marine environmental. Mar Pollut Bull 2006, 53:545-560

8. Moura JF, Cardoso M, Belo MSSP, Hacon S, Siciliano S: A interface da saúde pública com a saúde dos oceanos: produção de doenças, impactos socioeconômicos e relações benéficas. Ciênc Saúde Colet 2008, 1144:1-14.

9. Niencheski LF, Fillman G: Contaminantes: Metais, Hidrocarbonetos e Organoclorados. In Avaliação Ambiental de Estuários Brasileiros: Aspectos Metodológicos. 1st edition. Edited by Lana PC, Bianchini A, Ribeiro C, Niencheski LF, Fillman G, Santos CSG. Rio de Janeiro: Museu Nacional; 2006:63-118.
10. Tait RV, Dipper FA: Human impact on the marine environment. In Elements of Marine Ecology. 4th edition. Edited by Tait RV, Dipper FA. Oxford: Butterworth-Heinemann; 1998:395-435.

11. Strain PM, Macdonald RW: Design and implementation of a program to monitor ocean health. Ocean Coast Manage 2002, 45:325-355.

12. Stewart JR, Gast RJ, Fujioka RS, Solo-Gabriele HM, Meschke JS, Amaral-Zettler LA, Castillo E, Polz MF, Collier TK, Strom MS, Sinigalliano CD, Moeller PDR, Holland AF: The coastal environment and human health: microbial indicators, pathogens, sentinels and reservoirs. Environ Health 2008, 7:1-14.

13. Beeby A: What do sentinels stand for? Environ Pollut 2001, 112:285-298.

14. Furness RW, Camphuysen CJ: Seabirds as monitors of the marine environment. ICES J Mar Sci 1997, 54:726-737.

15. Burger J, Gochfeld M: Marine birds as sentinels of environmental pollution. Ecohealth 2004, 1:263-274.

16. Siciliano $S$, Alves VC, Hacon S: Aves e mamíferos marinhos como sentinelas ecológicas da saúde ambiental: uma revisão do conhecimento brasileiro. Cad Saúde Colet 2005, 13(4):927-946.

17. Thompson KR: The ecology of Manx shearwater Puffinus puffinus on Rhum, West Scotland, PhD thesis. University of Glasgow, Faculty of Science; 1987.

18. British Trust for Ornitology (BTO): Manx Shearwater Puffinus puffinus (Brünnich, 1764). http://blx1.bto.org/birdfacts/results/bob460.htm.

19. Guilford T, Meade J, Willis J, Phillips RA, Boyle D, Roberts S, Collett M, Freeman R, Perrins CM: Migration and stopover in a small pelagic seabird, the Manx shearwater Puffinus puffinus: insights from machine learning. Proc R Soc B 2009, 276:1215-1223.

20. Dale IM, Baxter MS, Bogan JA, Bourne WRP: Mercury in seabirds. Mar Pollut Bull 1973, 4(5):77-79.

21. Osborn D, Harris MP, Nicholson JK: Comparative tissue distribution of mercury, cadmium and zinc in three species of pelagic seabirds. Comp Biochem Phys C 1979, 64:61-67.

22. Garcia JG: Avaliação da concentração de metais traço em tecidos de petréis (Aves: Procellariidae) encontrados nas áreas central e sul das praias do Rio Grande do Sul. In Monograph. Fundação Universidade do Rio Grande, Oceanology Department; 2008.

23. Muirhead SJ, Furness RW: Heavy metal concentrations in the tissues of seabirds from Gough Island, South Atlantic Ocean. Mar Pollut Bull 1988, 19(6):278-283.

24. Thompson DR, Furness RW: The chemical form of mercury stored in South Atlantic Seabirds. Environ Polut 1989, 60:305-317.

25. Barbieri E, Garcia CAB, Passos EA, Aragão KAS, Alves JPH: Heavy metal concentration in tissues of Puffinus gravis sampled on the Brazilian coast. Rev Bras Ornitol 2007, 15(1):69-72.

26. Bekhit AE-D, Al-Amer S, Gooneratne R, Mason SL, Osman KA, Clucas L: Concentrations of trace elementals and organochlorines in Mutton bird (Puffinus griseus). Ecotox Environ Safe 2011, 74:1742-1746.

27. Bustamante P, Caurant F, Fowler SW, Miramand P: Cephalopods as a vector for the transfer of cadmium to top marine predators in the north-east Atlantic Ocean. Sci Total Environ 1998, 220(1):71-80.

28. Dorneles PR, Lailson-Brito J, Santos RA, Costa PAS, Malm O, Azevedo AF, Torres JPM: Cephalopods and cetaceans as indicators of offshore bioavailability of cadmium off Central South Brazil Bight. Environ Pollut 2007, 148(1):352-359.

29. Petry MV, Fonseca VSS, Krüger-Garcia L, Piuco RC, Brummelhaus J: Shearwater diet during migration along the coast of Rio Grande do Sul, Brazil. Mar Biol 2008, 154:613-621.

30. Norheim G: Levels and interactions of heavy metals in Sea Birds from Svalbard and the Antarctic. Environ Pollut 1987, 47:83-94.

31. Chen CY, Stemberger RS, Klaue B, Blum JD, Pickhardt PC, Folt CL: Accumulation of heavy metals in food web components across a gradient of lakes. Limnol Oceanogr 2000, 45(7):1525-1536.

32. Campbell LM, Norstrom RJ, Hobson KA, Muir DCG, Backus S, Fisk AT: Mercury and other trace elements in a pelagic Arctic marine food web (Northwater Polynya, Baffin Bay). Sci Total Environ 2005, 351:247-263.

33. Bundy A, Lilly RG, Shelton PA: A mass balance model of the NewfoundlandLabrador Shelf. Dartmouth: Canadian Technical Report of Fisheries and Aquatic Sciences 2310; 2000.

34. Bryman A, Cramer D: Quantitative data analysis with IBM SPSS Statistics 17, 18 and 19: A guide for social scientists. Hove: Psychology Press; 2011.

35. Scheuhammer AM: The chronic toxicity of aluminium, cadmium, mercury, and lead in birds: a review. Environ Pollut 1987, 46:263-295. 
36. Custer TW, Franson JC, Pattee $\mathrm{OH}$ : Tissue lead distribution and hematologic effects in american kestrels (Falco sparverius L.) fed biologically incorporated lead. J Wildl Dis 1984, 20(1):39-43.

37. Barton JC, Conrad ME, Harrison L, Nuby S: Effects of calcium on the absorption and retention of lead. J Lab Clin Med 1978, 91(3):366-376.

38. Cuvin-Aralar MLA, Furness RW: Mercury and selenium interaction: review. Ecotox Environ Safe 1991, 21:348-364.

39. Scheuhammer AM, Wong AHK, Bond D: Mercury and selenium accumulation in common loons (Gavia immer) and common mergansers (Mergus merganser) from Eastern Canada. Environ Toxicol Chem 1998, 17(2):197-201.

40. Eagles-Smith CA, Jackerman JT, Yee J, Adelsbach TL: Mercury demethylation in waterbird livers: dose-response thresholds and differences among species. Environ Toxicol Chem 2009, 28(3):568-577.

41. Ridlington JW, Whanger PD: Interactions of selenium and antioxidants with mercury, cadmium and silver. Fund App/ Toxicol 1981, 1:368-375.

42. Ji X, Hu W, Cheng J, Yuan T, Xu F, Qu L, Wang W: Oxidative stress on domestic ducks (Shaoxing duck) chronically exposed in a MercurySelenium coexisting mining area in China. Ecotox Environ Safe 2006, 64:171-177

43. Koeman JH, Van De Vem WSM, Goeij JJM, Tjioe PS, Van Haaften JL: Mercury and selenium in marine mammals and birds. Sci Total Environ 1975, 3:279-287.

44. Goede AA, Wolterbeek HT: Have high selenium concentrations in wading birds their origin in mercury? Sci Total Environ 1994, 144:247-253.

45. Caurant F, Amiard JC, Amiard-Triquet C, Sauriau PG: Ecological and biological factors controlling the concentrations of trace elements (As, Cd, $\mathrm{Cu}, \mathrm{Hg}, \mathrm{Se}, \mathrm{Zn}$ ) in delphinids Globicephala melas from the North Atlantic Ocean. Mar Ecol Prog Ser 1994, 103:207-219.

46. Kunito T, Nakamura S, Ikemoto T, Anan Y, Kubota R, Tanabe S, Rosas FCW, Fillmann G, Readman JW: Concentration and subcellular distribution of trace elements in liver of small cetaceans incidentally caught along the Brazilian coast. Mar Pollut Bull 2004, 49(7-8):574-587.

47. Lemos LS: Avaliação das concentrações de $\mathrm{Cd}, \mathrm{Cu}, \mathrm{Hg}, \mathrm{Mn}$, Se e Zn em pequenos cetáceos da costa norte do estado do Rio de Janeiro, Brasil. In Master thesis. Fundação Oswaldo Cruz, Escola Nacional de Saúde Pública; 2012.

48. Dietz R, Riget F, Born EW: An assessment of selenium to mercury in Greenland marine animals. Sci Total Environ 2000, 245:15-24.

49. Colabuono Fl, Taniquchi S, Montone RC: Organochlorine contaminants in albatrosses and petrels during migration in South Atlantic Ocean. Chemosphere 2012, 86:701-708.

50. Tanaka H, Ogi H, Tanabe S, Tatsukawa R, Oka N: Bioaccumulation and metabolism of PCBs and DDE in short-tailed shearwater Puffinus tenuirostris during its transequatorial migration and in the wintering and breeding grounds. Mem Nat Inst Polar Res 1986, 40:434-442.

51. Bourne WRP, Bogan JA: Polychlorinated biphenyls in North Atlantic seabirds. Mar Pollut Bull 1972, 3(11):171-175.

52. Jones KC, Voogt P: Persistent organic pollutants (POPs): state of the science. Environ Pollut 1999, 100(1-3):209-221.

53. Bailey S, Bunyan PJ, Rennison BD, Taylor A: The metabolism of 1,1-di(pchlorophenyl)-2,2,2-trichloroethane and 1,1-di(p-chlorophenyl)-2,2dichloroethane in the pigeon. Toxicol Appl Pharmacol 1969, 14:13-22

54. Moisey J, Fisk AT, Hobson KA, Norstrom RJ: Hexachlorocyclohexane (HCH) Isomers and Chiral Signatures of $\mathrm{a}-\mathrm{HCH}$ in the Arctic Marine Food Web of the Northwater Polynya. Environ Sci Technol 2001, 35:1920-1927.

55. Guruge KS, Watanabe M, Tanaka H, Tanabe S: Accumulation status of persistent organochlorines in albatrosses from the North Pacific and the Southern Ocean. Environ Pollut 2001, 114(3):389-398,

56. Bann JM, Decino TJ, Earle NW, Sun Y-P: The fate of Aldrin and Dieldrin in the animal body. J Agric Food Chem 1956, 4(11):937-941.

57. Agency for Toxic Substances and Disease Registry (ATSDR): Toxicological Profile for Endrin. Atlanta 1996.

58. Kapoor IP, Metcalf RL, Nystrom RF, Sangha GK: Comparative metabolism of methoxychlor, methiochlor, and DDT in mouse, insects, and in a model ecosystem. J Agric Food Chem 1970, 18(6):1145-1152.

59. Agency for Toxic Substances and Disease Registry (ATSDR): Toxicological Profile for Endosulfan. Atlanta 2000.

60. Agency for Toxic Substances and Disease Registry (ATSDR): Toxicological Profile for Mirex and Cholordecone. Atlanta 1995.

61. Agency for Toxic Substances and Disease Registry (ATSDR): Toxicological Profile for Hexachlorobenzene. Atlanta 2002
62. Maervoet J, Chu SG, De Vos S, Covaci A, Voorspoels S, De Schrijver R, Schepens P: Accumulation and tissue distribution of selected polychlorinated biphenyl congeners in chickens. Chemosphere 2004, 57:61-66.

63. Walker $\mathrm{CH}$ : Persistent pollutants in fish-eating sea birds - bioaccumulation, metabolism and effects. Aquat Toxicol 1990, 17:293-324

64. Ferreira AP: Measurement of chlorinated dioxins, furans and PCBs in Ardea alba Great Egret, and Puffinus puffinus Manx Shearwater: Ilha Grande Bay, Rio de Janeiro, Brazil. J Integrat Coast Zone Manage 2012, 12(1):7-15.

65. Austin B: Vibrios as causal agents of zoonoses. Vet Microbiol 2010, 140:310-317.

66. Miyasaka J, Yahiro S, Arahira Y, Tokunaga H, Katsuki K, Hara-Kudo Y: Isolation of Vibrio parahaemolyticus and Vibrio vulnificus from wild aquatic birds in Japan. Epidemiol Infect 2006, 134(4):780-785.

67. Halpern M, Senderovich Y, Izhaki I: Waterfowl - the missing Link in epidemic and pandemic cholera dissemination? PLoS Pathog 2008, 4(10):1-3.

68. Ogg JE, Ryder RA, Smith HL Jr: Isolation of Vibrio cholerae from aquatic birds in Colorado and Utah. Appl Environ Microbiol 1989, 55(1):96-99.

69. Buck JD: Isolation of Candida albicans and Halophilic Vibrio spp. from Aquatic Birds in Connecticut and Florida. Appl Environ Microbio/ 1990, 56(3):826-828.

70. Roges EM, Souza RL, Santos AFM, Siciliano S, Ott PH, Moreno IB, Pereira CS, Reis EMF, Lazaro NS, Rodrigues DP: Distribution of Vibrio sp. in marine mammals, seabirds and turtles beached or accidentaly captured in fishing nets in coastal regions of Brazil. In Vibrios In The Environment 2010 Mississipi 2010:S30-S32. Abstract.

71. Lee JV, Bashford DJ, Donovan TJ, Furniss AL, West PA: The incidence of Vibrio cholerae in water, animals and birds in Kent, England. $J$ Appl Bacteriol 1982, 52:281-291.

72. Hubálek Z: An annotated checklist of pathogenic microorganisms associated with migratory birds. J Wildl Dis 2004, 40(4):639-659.

73. Rabbani $\mathrm{GH}$, Greenough WB III: Food as a vehicle of transmission of cholera. J Diarrhoeal Dis Res 1999, 17(1):1-9.

74. Valentin $\mathrm{J}$ : Analyse des paramètres hydrobiologiques dans la remontée de Cabo Frio (Brésil). Mar Biol 1984, 82:259-276.

75. Leite GS, Dourado MS, Candella RN: Estudo preliminar da climatologia da ressurgência em Arraial do Cabo,RJ. In XI ENAPET; Florianópolis. Edited by XI ENAPET Amostra de Atividades Petianas. 2006:1-11.

76. Burke V, Robinson J, Gracey M, Peterson D, Partridge K: Isolation of aeromonas hydrophila from a metropolitan water supply: seasonal correlation with clinical isolates. Appl Environ Microbiol 1984, 48(2):361-366.

77. Moyer NP: Clinical significance of Aeromonas species isolated from patients with diarrhea. J Clin Microbiol 1987, 25(11):2044-2048.

78. Pereira CS, Amorim SD, Santos AFM, Reis CMF, Theophilo GND, Rodrigues DP: Caracterização de Aeromonas spp isoladas de neonatos hospitalizados. Rev Soc Bras Med Trop 2008, 41(2):179-182.

79. Staples P: Aeromonas, Plesiomonas and Vibrio bacteria isolated from animals in New Zeland. Surveillance 2000, 27(1):3-4

80. Lévesque B, Brousseau P, Simard P, Dewailly E, Meisels M, Ramsay D, Joly J: Impact of the ring-billed gull (Larus delawarensis) on the microbiological quality of recreational water. Appl Environ Microbiol 1993, 59(4):1228-1230.

81. Lévesque B, Brousseau P, Bernier F, Dewailly E, Joly J: Study of the bacterial content of the ring-billed gull droppings in relation to recreational water quality. Water Res 2000, 34(4):1089-1096.

82. Macleod WD, Brown DW, Friedman AJ, Burrows DG, Maynes O, Pearce RW, Wigren CA, Bogar RG: Standard Analytical Procedures of the NOAA National Analytical Facility, 1985-1986. Extractable Toxic Organic Compounds. Springfield: U.S. Department of Commerce, NOAA Technical Memorandum NMFS F/NWC-92; 1986

83. Wade TL, Cantillo AY: Use of Standards and Reference Materials in the Measurement of Chlorinated Hydrocarbon Residues, Chemistry Workbook. Silver Spring: U.S. Department of Commerce, NOAA Technical Memorandum NOS ORCA 77; 1994

84. Noguerola I, Blanch AR: Identification of Vibrio spp. with a set of dichotomous keys. J App/ Microbio/ 2008, 105(1):175-185.

85. Janda JM, Abbot SL: The genus aeromonas: taxonomy, pathogenicity, and infection. Clin Microbiol Rev 2010, 23(1):35-73.

doi:10.1186/2046-9063-10-6

Cite this article as: Cardoso et al:: The Manx shearwater (Puffinus puffinus) as a candidate sentinel of Atlantic Ocean health. Aquatic Biosystems 2014 10:6 